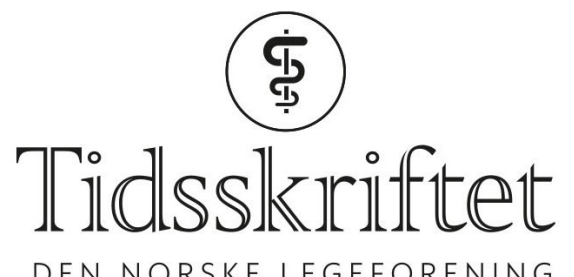

DEN NORSKE LEGEFORENING

\title{
E. Hem svarer
}

SPRÅKSPALTEN

\section{ERLEND HEM}

E-post: erlend.hem@medisin.uio.no

Erlend Hem (f. 1970) er dr.med., fagsjef og redaktør for Tidsskriftets språkspalte.

Noen pasienter får hjerneslag mens de er innlagt i sykehus. Man skulle tro at det var en fordel - hjelpen er nær. Det viser seg imidlertid at det kan være motsatt. Disse pasientene får ofte forsinket akuttbehandling fordi sykehuspersonalet ikke tenker på muligheten av slag, men tror at pasienten bare er trett og sliten. Vi trenger et ord for dette. På engelsk heter det in-hospital stroke. Kanskje vi kan foreslå tilsvarende: hjerneslag $i$ sykehus?

Det andre ordet som Gro Owren Nygaard nevner, iktus, er godt etablert i norsk. I de medisinske ordbøkene forklares det med st $\varnothing t$, slag, sjokk, anfall, angrep (1-3). I nevrologien benyttes det på en litt annen måte, som betegnelse på starttidspunktet for en plutselig innsettende akutt tilstand, som hjerneslag eller epileptisk anfall. Dette er i tråd med definisjonen i Oxford English Dictionary: «A stroke, seizure, or fit» (4). Ordet stammer fra det latinske icere som betyr «å slå», altså noe som skjer plutselig. Vi kjenner det igjen i ictus cordis, støtet fra hjertespissen, og preiktal eller postiktal, om noe som har skjedd før eller etter et anfall. I engelsk brukes det på samme måte, med avledet form ictal (norsk: iktal).

Jeg tror at iktus i denne betydningen kan fungere bra. Det skulle ikke være nødvendig å lage et avløserord for et godt fornorsket, latinsk uttrykk. En betydningsutvidelse er ofte lettere å få til enn å etablere noe helt nytt.

\section{LITTERATUR:}

1. Iktus. I: Lindskog BI. Gyldendals store medisinske ordbok. 2. utg. Oslo: Gyldendal, 2003: 233.

2. Iktus. I: Øyri A. Norsk medisinsk ordbok. 9. utg. Oslo: Samlaget, 2011: 467.

3. Iktus. I: Nylenna M, red. Medisinsk ordbok. 7. utg. Oslo: Kunnskapsforlaget, 2009: 205.

4. Ictus. I: Oxford English Dictionary. http://www.oed.com/view/Entry/90934 (28.7.2017).

Publisert: 16. oktober 2017. Tidsskr Nor Legeforen. DOI: 10.4045/tidsskr.17.0804

(C) Tidsskrift for Den norske legeforening 2020. Lastet ned fra tidsskriftet.no 